\title{
An invasive species: Leptoglossus occidentalis (Heidemann) how does it affect forestry activities?
}

\author{
Salih PARLAK \\ Bursa Technical University, Faculty of Forestry, Bursa, TURKEY \\ salih.parlak@btu.edu.tr
}

Received Date: 14.02.2017

Accepted Date: 09.06.2017

\section{Abstract}

Aim of study: Leptoglossus occidentalis which is first identified by Heidemann at North America in 1910 spread quickly after WW II. Although it was first seen in 1999 in Europe has swept the continent in 10 years. First damage observation in Turkey reported in Kozak Basin of Bergama on cones of stone pine trees which has valuable edible seeds. The seed yield loss started in 2005 and reached to a peak in 2009. In addition to high early age conelet loss, rate of emptiness of cones has sometimes reached to $90 \%$. The bug causes decrement in seed formation and seed germination ability significantly by causing early stage conelet loss and destroying endosperm parts of mature cones. In respect of forestry activities decrement of seed resources caused due to bug damage will have negative impact on natural regeneration activities in Turkey and probably will end in failure. In this study, it was aimed to determine the severity of damage caused by the collecting of cone samples from the stone pine forests in our country.

Area of study: Without making any discrimination either planted or natural or any altitude or any aspect, stone pine cones have been collected from 42 localities which are distributed all around Turkey.

Material and Methods: Weight and size of cones have been measured and seeds extracted by holding at 55 ${ }^{0} \mathrm{C}$ in climate cabinet, then damage on seeds of $L$. occidentalis and unshelled seed yield determined.

Main results: Empty seed formation in stone pine cones varies between $\% 14$ and $98 \%$, depending on the region. There is no difference between natural or plantation forests in terms of empty seed formation.

Research highlights: All necessary control strategies should be developed against this bug which has high potential as technic and cost for affecting forestry.

Keywords: Leptoglossus occidentalis, Damages

\section{İstilacı bir tür: Leptoglossus occidentalis (Heidemann) ormancılık}

\section{faaliyetlerini nasıl etkiler?}

Özet

Çallşmanın amacı: Heidemann tarafından 1910 yilında Kuzey Amerika'da ilk kez tanımlanan Leptoglossus occidentalis İkinci Dünya Savaşından sonra hızlı bir şekilde yayılmaya başlamış, Avrupa'da ilk kez 1999 y1lında görülmesine rağmen on yıl içerisinde tüm kıtayı sarmıștır. Tohumu yenen değerli bir tür olması itibarıyla Ülkemizdeki ilk zarar gözlemleri İzmir-Kozak Havzasında fistıkçamlarında görülmüş, 2005 yılında başlayan tohum verimindeki azalma, 2009 yilında zirve noktasına ulaşmıştır. İlk dönemde görülen erken dökülmeler ve kozalaklardaki dolu tohum oranları bazen \% 90'lara varan oranlara ulaşmıştır. Erken dönem kozalak dökümüne neden olması ve olgunlaşan kozalakların endosperm kısımlarına zarar vermesi nedeniyle tohum oluşumunu ve tohumun çimlenmesini önemli ölçüde azaltmaktadır. Ormancılık çalışmaları açısında irdelendiğinde; böcek zararı nedeniyle tohum kaynağındaki azalmalar ormanlarımızdaki doğal gençleştirme çalı̧̧alarını olumsuz etkileyecek, çalışmaların başarısızlıkla sonuçlanmasına neden olabilecektir. Çalışmada, ülkemizdeki fistıkçamı meşcerelerinden kozalak örnekleri alınarak böceğin meydana getirdiği zarar şiddetinin belirlenmesi amaçlanmıştır.

Çalışma alanı: Türkiye'de fıstıkçamı alanlarından doğal ya da plantasyon ayrımı yapılmaksızın, yükselti ve bakı farkı gözetilmeksizin 42 lokaliteden olgun fistıkçamı kozalakları toplanmıştır.

Materyal ve Yöntem: Kozalakların ağırlık ve en-boy ölçüleri alınmış, iklim dolabında $55{ }^{\circ} \mathrm{C}$ 'de tohumlar çıkarılarak L. occidentalis' in fistıkçamı tohumlarında meydana getirdiği zararlar ve iç fistık randımanları belirlenmiştir.

Sonuçlar: Fıstıkçamı kozalaklarında boş tohum oluşumu yörelere göre \% 14 ile \% 98 arasında değişmektedir. Boş tohum oluşumu bakımından doğal veya plantasyon ormanlarında arasında fark görülmemektedir.

Araştırma vurguları: Ormancıllk faaliyetlerimizi teknik ve mali olarak etkileme potansiyeli yüksek olan bu böceğe karşı acilen mücadele stratejileri geliştirilmelidir.

Anahtar kelimeler: Leptoglossus occidentalis, Zararlar 


\section{Introduction}

Although Leptoglossus occidentalis was first discovered in Turkey in 2009 (Arslangündoğdu and Hizal, 2010), it can be suggested that it entered into the country in early 2000's given the signs of inefficiency in the stone pine trees especially in Bergama Kozak Basin. The damage caused by $L$. occidentalis such as drop of the newly formed cones and the formation of empty seeds that mature occurred in those years. It is quite natural that the first signs of the damage were observed in the stone pine trees in Kozak Basin because they are important non-wood forest products and monoculture source of income.

The largest distribution areas of this species in Turkey are located in Bergama Kozak Basin (15265 ha) and Aydın-Koçarlı (16707 ha) (K1lc1 et al. 2014), while the prominent production sectors are concentrated in these areas. In particular, it accounts for a big part of the income of 17 villages in Bergama-Kozak region and increases their economic prosperity. Stone pine cultivation has turned into monoculture in these areas. Due to the conelet drops and formation of empty seeds contained in mature cones in the last decade, the producers who subsisted on stone pine have faced some challenges and the enterprises were either shut down or had to modify their business model (URL 1). During the same period, the implementation units of the Directorate General of Forestry also submitted similar complaints that conelets fell and the seeds contained in mature cones were empty, and investigations were carried out regarding the problems faced.

Its natural distribution area covers 50790 hectares in Turkey, forests have been established in recent years with these trees as a social and income-generating species on an area of 132340 hectares through afforestation efforts; therefore, they are now located on an area of 183128 hectares and it ranked in the second place with respect to surface area in the recent inventory studies (K1lc1 et al. 2014). Spain has the largest distribution area and highest number of trees $(490000 \mathrm{Ha})$ across the world while Portugal follows Turkey with 130300 hectares (K1lc1 et al. 2014; Sousa et al., 2014; Mutke et al 2015).
Leptoglossus occidentalis leads to damage not only in Turkey but also in the entire Mediterranean Basin and causes a great damage in the distribution areas of stone pine. It was emphasized that it reduced stone pine production by $95 \%$ especially in Italy (Bates et al., 2002a). It was found in the studies performed in Kozak Basin that all of the cones fell in some years, while only one out of 111 cones that were formed in spring remained undamaged in autumn (Özçankaya et al, 2010). The damage caused by the insects during the early cone period (conelet period) kills embryo and leads to the fall of the conelets that are formed and thus reduces the number of filled and undamaged seeds in later periods (Woods, at al, 2015), (Figure 12).

The research conducted in 2014 in Trabzon- Kalenema Stream, which is the natural distribution area of stone pine, also revealed that there was an extensive cone drop. Furthermore, the detailed research conducted in 2015 also demonstrated that the insects encountered in Bursa Cumalıkızık Village were also present in abundance and caused damage in Uludağ National Park. During the meetings held with the producers and representatives of forest service in the distribution areas of stone pine, they stated that stone pine was present extensively in all distribution areas in Turkey.

Leptoglossus occidentalis damages not only the stone pine trees but also the seeds of all coniferous species that are distributed in Turkey. The seeds of stone pine are edible and have a high economic return; therefore, the damage on the seeds is considered from the economic perspective. However, there is a significant threat posed to the seeds of the other forest trees. The studies conducted revealed that the seeds of the other species were also damaged considerably. The germination rate that varied from $60 \%$ to $80 \%$ in Pinus nigra in the past years was found to fall to 19\% in 2016 (Anonymous 1). Therefore, this pest has a huge potential to influence the forestry activities. Decreased seed resources due to the damage of the insects may result in challenges especially with regard to natural regeneration and reduction of germplasm. 


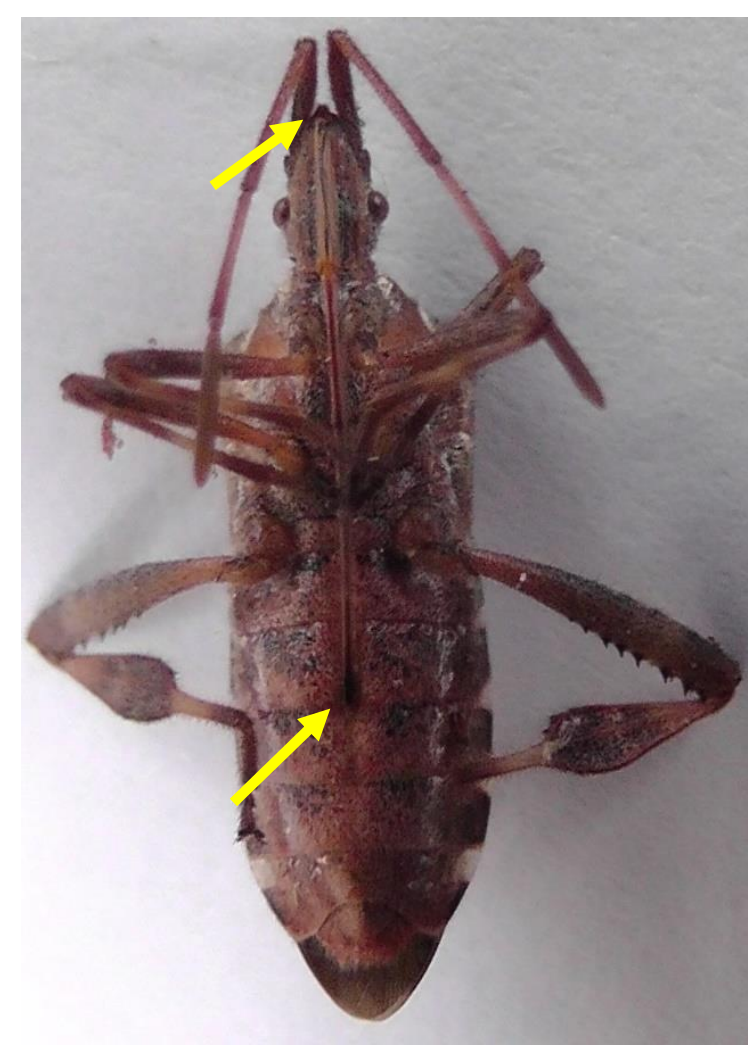

Figure 1. Adult of L. occidentalis and its stilet

\section{Distribution of Leptoglossus occidentalis}

Although L.occidentalis was first described by Heidemann in North America in 1910 , it spread rapidly to the central and east America after the World War II (Leiseur et al., 2014) This insect that was first seen in Italy in 1999 (Tescari, 2001) spread to all over the country rapidly, while it was also found in Switzerland in 2005 (Wittenberg, 2005). It spread very rapidly following 2000 , while it was colonized in a big part of the continent from Norway to Sicily and from
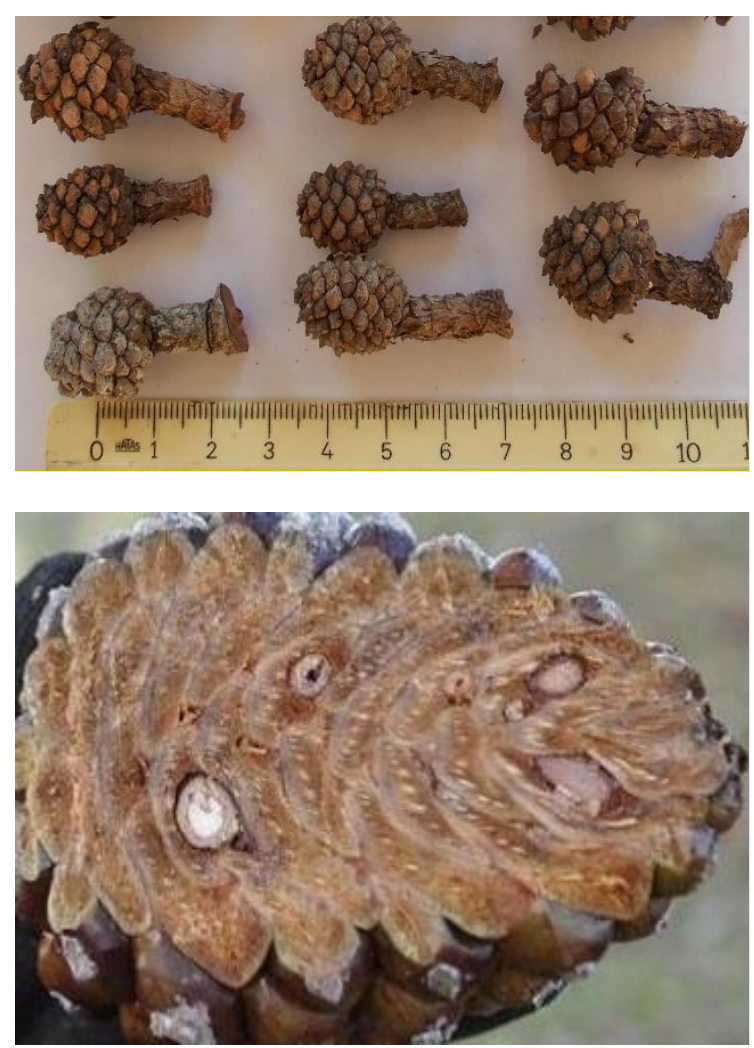

Figure 2. Damage caused by Leptoglossus occidentalis in the newly formed conelets and mature cones

Portugal to Turkey just within a decade (Fent and Kment 2011). In 2012, it was observed in Russia and Ukraine (Gapon, 2012). In 2013, it spread to Far East Asia (Ahn et al. 2013), while in 2010, it was found in Korea (Chun-Sik Yoon et al, 2012) (Figure 3). It was observed in East Asia and Japan in recent years (Ishikawa and Kikuhara 2009). Although it was first encountered in Turkey in 2009 (Arslangündoğdu and Hizal 2010), it was understood that it spread to the entire country in the last 5-6 years. 


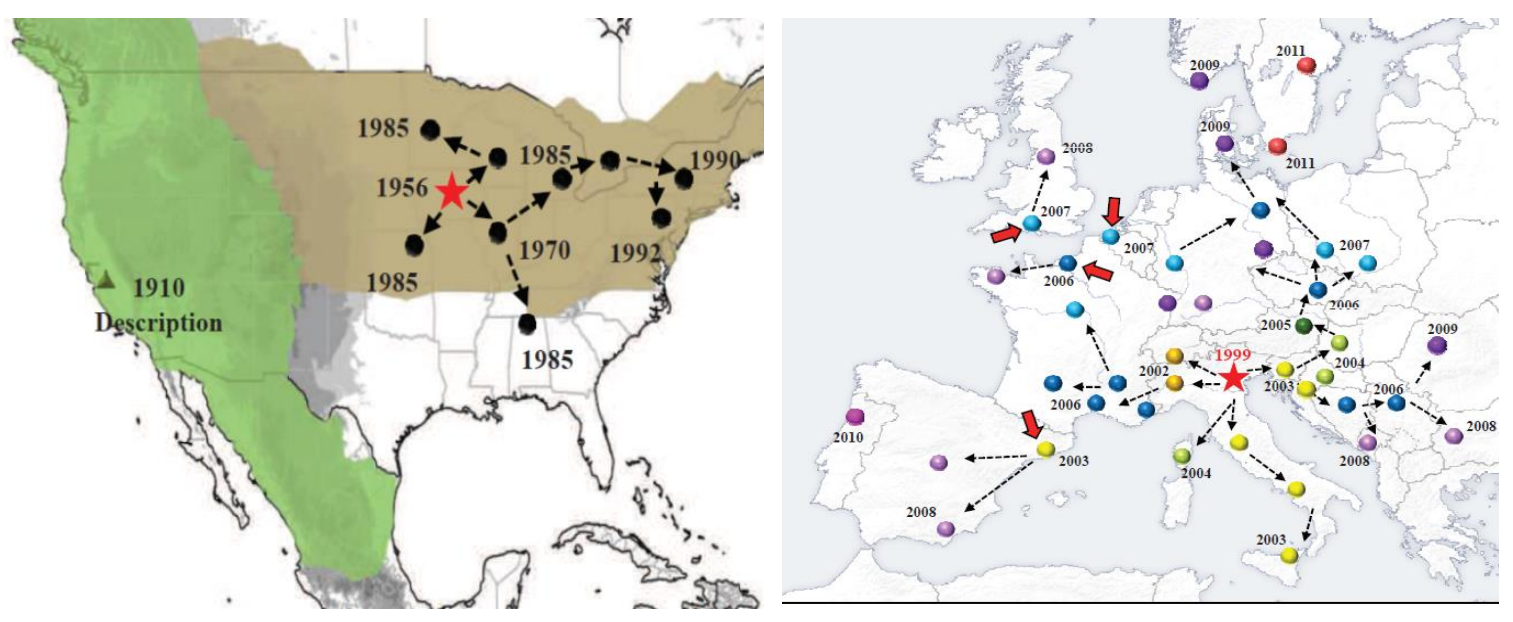

Figure 3. Distribution in USA and Europe (Leiseur et al., 2014)

In Europe and Portugal, Leptoglossus occidentalis was first detected in areas where there was a considerable amount of commercial activity and there were sea ports (Dusoulier et al. 2007; Souza and Naves 2011). It is thought suspected that the eggs, nymphs or adults of the insect in the chips were carried away and spread by the tree or seed materials (Fent and Kment 2011; Jamâa et al., 2013; Lesieur, et al., 2014). International trade of ornamental plants between the continents also resulted in the spread of exotic insects. This also disrupted the balance between the natural flora and fauna in addition to the economic losses. Despite all the constraints and quarantine measures, it is difficult to slow down the spread of $L$. occidentalis that is an invasive species (Jucker, 2005). It was detected for the first time in Africa in 2011 and 2012 (Jamâa et al., 2013). It is suggested that the insect arrived in Turkey through the imported cones. The entry of the insect to Turkey through the cones imported by the companies and the first signs of damage observed in
Bergama-Kozak Basin seem to support this suggestion.

\section{Recognition of the insect and its characteristics}

The adults are 15-20 $\mathrm{mm}$ long, have long antennas and have a colour range from dark red to greyish-brown and they are distinguished by the white marks in the areas around their abdomens. The parts of their mouth are in the shape of a long needle and they extend their mouths between their legs when they don't feed (EPPO, 2010; Fent and Kment 2011; Jamâa et al., 2013; Ogden, 2013).

They are distinguished by the white zigzag mark on their bodies (Walker, 1913). The tibia of the insects is enlarged like a leaf, which is a characteristic feature of these insects (Galli, 1992), (Figure 4). The reason why they are referred to as "leaf-legged insects" is this leaf-shaped enlargement on tibia. Another characteristic feature of these insects is the slightly $\mathrm{W}$-shaped zigzag marks in the front parts of their wings (Figure 5). 


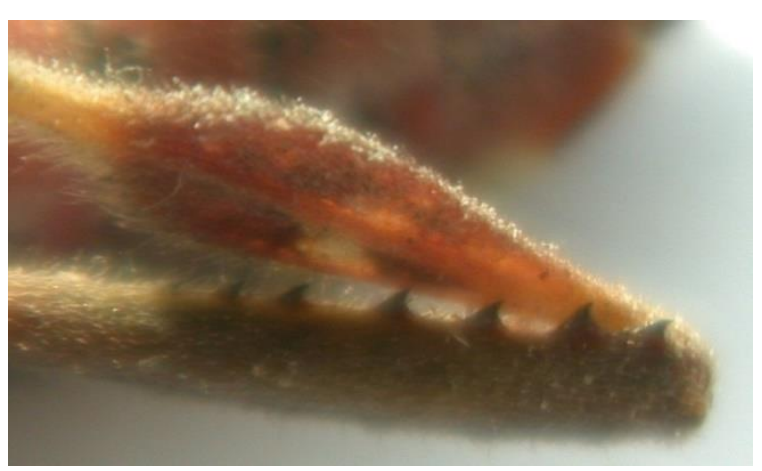

Figure 4. Enlargement in the shape of a leaf on tibia (S.Parlak)

The adult insects are highly capable of flying, they are prepared to fly when disturbed and they have a whizz-like sound while flying (Reid et al., 2009; Resh and Carde, 2009; Fent and Kment 2011; Jamâa et al., 2013).

\section{Materials and Methods Materials}

The material of this study consists of the scientific studies conducted on L.occidentalis, the data obtained from the field surveys conducted to explore the damage caused by $L$. occidentalis in stone pine. Efforts were made to collect the cones before they split open and shed the seeds. To this end, minimum 5 cones that were matured in 2016 were collected from 42 different locations of 20 Forestry Directorates in natural stone pine forests or those ones that were established through plantation and 20 adults of $L$. occidentalis with unknown sex to determine their length and stilet.

\section{Methods}

The cones were labelled according to the locations where they were collected and maintained in a drying-oven for 48 hours at $55{ }^{\circ} \mathrm{C}$ to enable the cones to split open. The seeds were kept at $+4{ }^{\circ} \mathrm{C}$ to avoid any degradation and to perform the measurements.

The weight per 1000 grains and inner kernel yield of the seeds that were extracted, their fill rate and inner kernel yield were measured and the types of visible damage on the inner kernels were determined. The data obtained were subjected to statistical analysis and graphs were prepared.

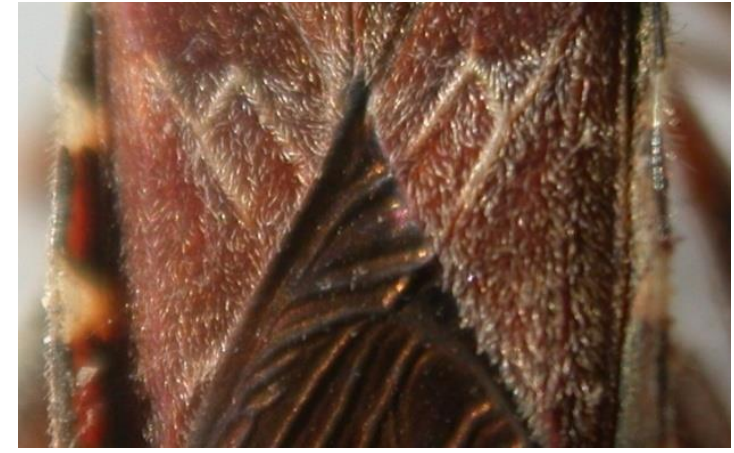

Figure 5. Characteristics zigzags on wings (S.Parlak)

The adult individuals of $L$. occidentalis were collected in Bursa-Uludağ in November 2016 and their length and stilet were measured with caliper without sorting out their sex.

The purpose of the study was to determine the severity of the damage caused by the insects in stone pine seeds; therefore, it was aimed that the cones represented the location where they were collected, and thus aspect and elevation were not considered as a factor.

\section{Results and Discussion \\ Damage caused by Leptoglossus occidentalisin stone pine}

The insects insert their stilet directly into the seeds and suck their oil and protein content (Bates et al. 2001). They insert the parts of their mouths in the shape of a syringe into the seeds contained in the cones. They leave their saliva in the seed content and suck the seeds. Mature cones do not appear to have an external damage due to sucking. The insects suck the newly developing cones and lead to the fall of young cones. The oil and protein content of the seeds are sucked and the seeds are left totally empty, which leads to the shrinkage of the inner parts of the cones and also varying degrees of damage (Bates et al. 2000, Bates et al., 2002b; Strong et al. 2001; EPPO. 2010). Seeds shrink due to the damage in the early period that is the period before the seed bolls are hardened and the formation of seeds is reduced (Strong et al. 2001). In this study, it was found average bug length $18.8 \mathrm{~mm}$ and average stilet lenght $12.3 \mathrm{~mm}$. 
The fact that the cone drop and damage in the seeds of stone pine after 2000 were caused by $L$. occidentalis remained unknown despite so many years of research (Strong 2006). After these insects were detected in Europe by the end of 1990's, it was reported that cone losses were observed in stone pine trees (Peverieri et al., 2013). In the light of the studies conducted, it was found out that these insects had a great impact on the product losses due to cone drop during pine nut production in the Mediterranean Basin (Bracalini et al., 2013).

In Italy, conelet drop from stone pine trees may go up to $80 \%$ (Roversi, 2009), while the damage caused by these insects may decrease the yield by up to $95 \%$ in the natural areas where stone pine is cultivated in Europe especially in Mediterranean

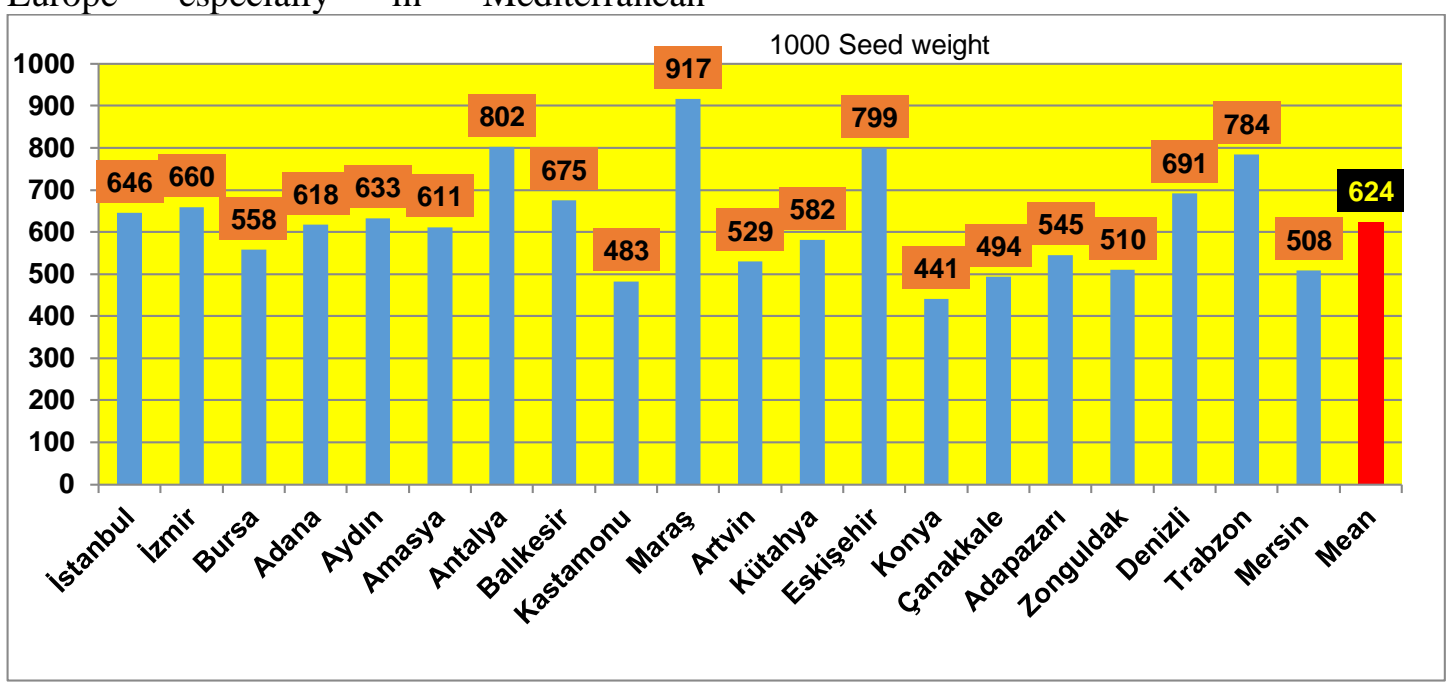

Figure 6. Weight per 1000 grains of seeds by regions

Regarding empty seed ratios, the highest number is found in Trabzon (98\%) and overall average empty seed ratio is about $59 \%$. There is no important difference
Countries. It was found that the damage was up to $60 \%$ in one-year stone pine cones and up to $80 \%$ in two-year stone pine cones. The annual production of stone pine seeds is 40 thousand tones in Italy, whereas the production decreased rapidly following the onset of the damage caused by these insects and stone pine cultivation decreased by $95 \%$ in 2009 (Bates et al., 2002a; Roversi et al. 2011). The inner kernels of the damaged seeds wrinkle and cones fall (Brambila, 2007). These insects that have invaded Europe are considered to be responsible for the significant yield loss in stone pine trees (Roversi et al. 2011; Bracalini et al. 2013).

Regarding thousand grain weight location Maraş is found highest and avarage weight is 624 gr. (Figure 6). 


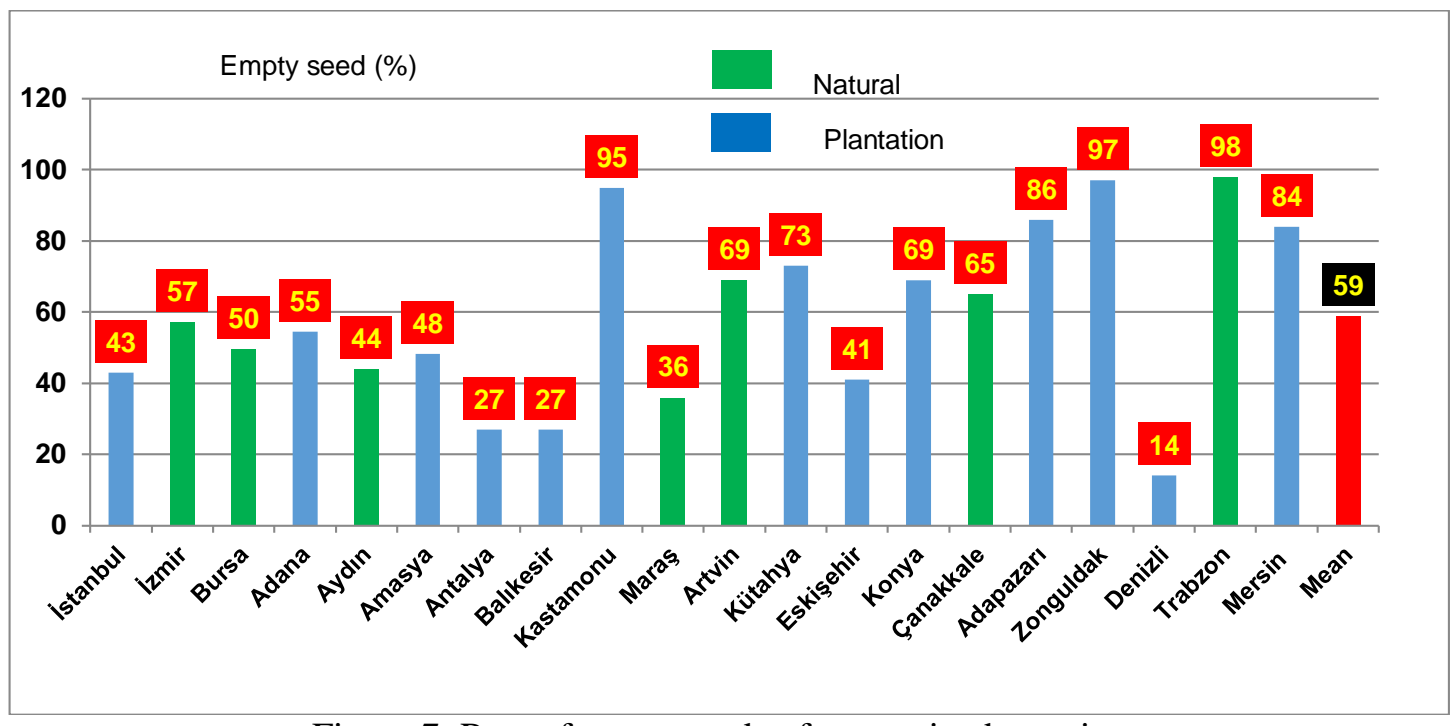

Figure 7. Rate of empty seeds of stone pine by regions

The rate of empty seeds in stone pine ranged from $15 \%$ to $24 \%$ in 5 natural distribution areas in 1980, while it went up to 27\%- 69\% with an increasing trend in 2016.
Although the inner kernel weight did not change significantly, the rate of empty seeds increased in all regions (Figure 8).

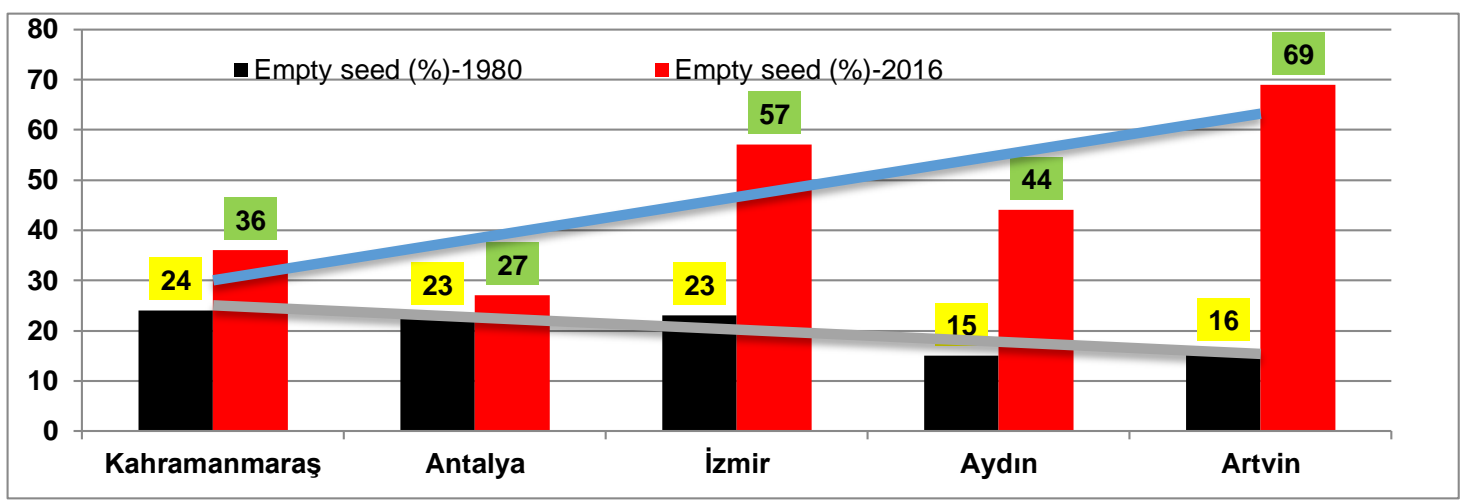

Figure 8. Rate of empty seeds of stone pine in 1980 (Iktüeren,, 1980) and in 2016

\section{Impact on the other tree species}

It is reported that L.occidentalis leads to the loss of seeds in the one-year cones of Pinus contorta Dougl. and Pinus monticola by up to $75 \%$ (Bates et al., 2000; Bates et al., 2002b; Strong et al., 2001). It has been observed to reduce the formation of seeds and seedlings in some coniferous species by around 50\% (Blatt, 1994; Bates et al. 2000; Bates et al. 2001). In Sicily, it was found on Pinus halepensis, $P$. laricio, $P$. pinea, $P$. nigra, Pseudotsuga menziesii at an elevation of 1430 meters (Maltese et al. 2009). Similarly in Northern Italy, it was encountered on Pinus strobus, P. sylvestris, P. nigra, Pseudotsuga sp (Hellrigl, 2006). It was first discovered in Turkey in 2009 (Arslangündoğdu and Hizal, 2010) however, there isn't any study conducted yet to explore the damage it caused on the coniferous species and its severity.

Leptoglossus occidentalis feeds on the cones of the coniferous species and leads to a severe damage in the pine forests in Northern America. The main host of the insect is the coniferous species including primarily the pine trees. It may also lead to little damage on such species as Pseudotsuga menziesii. It has been increasingly reported that it damages Juniperus, Tsuga, Picea, Cedrus, Calocedrus species as well. In a study conducted on Pseudostuga menziesii (Mirb.) 
it was found that two-week feeding period of the females in the late stage decreased the formation of filled seeds by $70 \%$ (Koerber 1963, Cambell and Shea 1990, Mjøs et al. 2010; Bates et al. 2000, Bates et al., 2002b). It is reported that the degree of loss in the seed yards of Pinus echinata goes up to $83 \%$ (EPPO, 2010). It leads to a loss in duglas trees by $41 \%$ (Koerber, 1963). The controlled trials showed that the damage caused by the nymphs on Pinus strobus decreased the seed formation by $75 \%$. Furthermore, the seed retention rate decreased by $47 \%$ (Bates et al, 2002a).

The damage caused due to the feeding pattern of $L$. occidentalis may vary depending on the development stage of the seeds. If the damage occurs before the seed boll hardens, the seed collapses or partially develops. If the damage occurs when the boll starts hardening, the seed decays and withers. The damage caused by the insect was reported to be $55 \%$ under laboratory conditions (Krugman and Koerber, 1969). The fact that the second-stage nymphs feed on the cones of Pinus echinata just for four weeks was found to result in the cone drop by $100 \%$. Similar damage such as the destruction of embryo that leads to cone drop also occurs by the end of summer when the nymphs still feed (DeBarr and Kormanik, 1975).

\section{Possible effects on forestry activities}

L. occidentalis feeds on primarily cones and seeds, which results in conelet drop and seed loss (Koerber, 1963; Hedlin et al., 1981;
Cibrian-Tovar et al., 1986; Strong, 2006; Santini, 2009). The insect poses a threat to not only the seed stands but also the natural stands and leads to a great danger during the natural regeneration of coniferous species due to the lack of appropriate climate conditions and natural enemies (Roversi et al. 2011; Tamburini et al. 2012; Bracalini et al. 2013; Lesieur at al 2014). It has been reported that there was a decrease in seed yards by up to $80 \%$. Therefore, it reduces the seed quality and vitality in conifers and directly results in economic loss (Bracalini et al, 2014). The seed formation capacity of mature seeds decreases by $80 \%$ due to the mild and medium feeding damage compared to the controls (Bates et al., 2001). These studies confirm that L. occidentalis need to be taken into account in the future forest strategies. Moreover, the associations regarding the use of the same food sources by these invasive species and other insect species should also be explored in future studies (Lesieur, et al., 2014).

Adults and nymphs feed on the endosperm of the seeds, leading to the damage of the seeds and high drop rate. They may lead to seed loss up to $80 \%$ in conifers (Reid et al, 2009; Resh and Carde, 2009). A study conducted on Duglas demonstrated that mild to medium damage decreased the seedling emergence by $80 \%$ compared to the controls (Bates, 1997). A study conducted on Pinus nigra showed that they reduced the germination rate to less than $20 \%$ even at mild damage severity (Lesieur et al. 2014), (Figure 9).
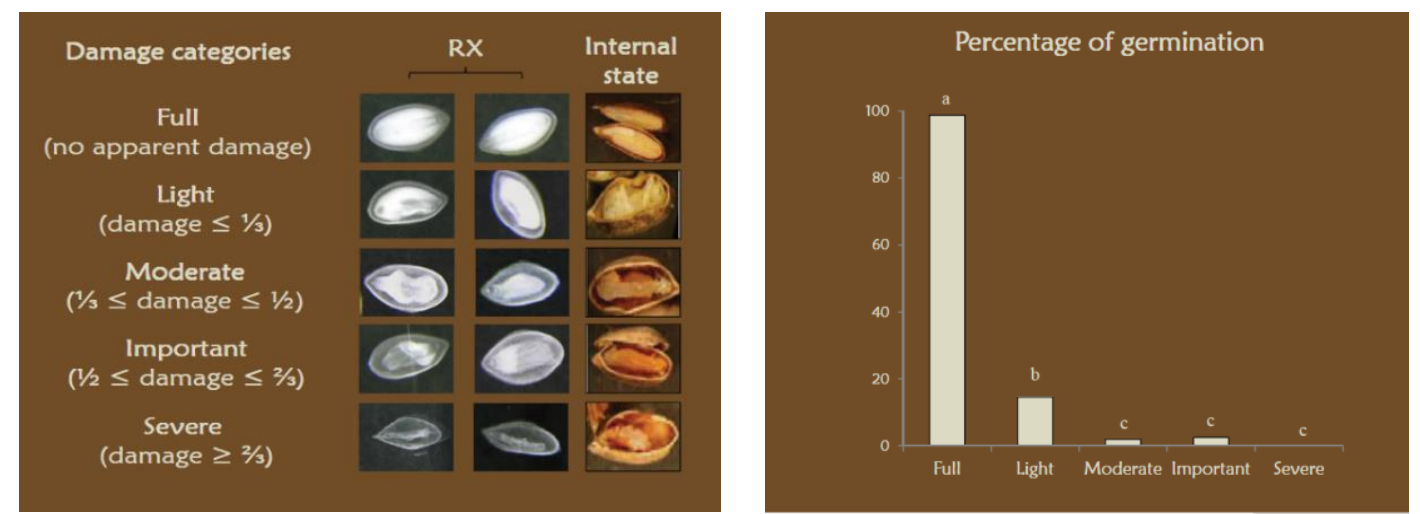

Figure 9. Germination rates according to the severity of damage in Pinus nigra (Lesieur et al., 2014) 
The studies conducted by Lesieur et al. (2014) revealed that the germination rates were reduced to less than $30 \%$ also in the other tree species even at mild severity. The medium degree of damage reduced the germination to less than 5\% (Figure 10).

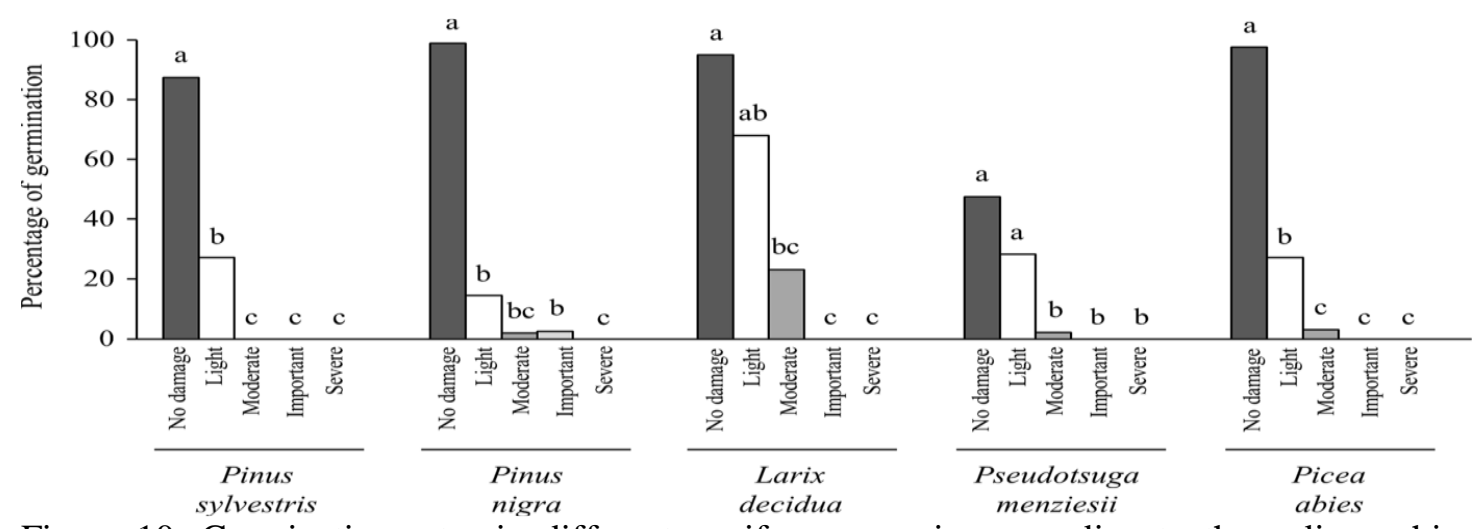

Figure 10. Germination rates in different coniferous species according to the radiographic damage (Lesieur et al., 2014)

Fleischer et al., (2010) demonstrated that only $9.29 \%$ of the oak (Q. candicans) seeds were germinated in case of visible damage caused by L. occidentalis.

\section{Conclusion}

Although Leptoglossus occidentalis is a new invasive species in Turkey, it has been distributed widely in a very short period of time. The first signs of damage were observed in 2004-2005 in Bergama Kozak Basin whereas the severity of the damage has increased extensively and damaged the stone pine trees in the other regions as well. The cone drop it cause has increased up to $95 \%$ in some of the regions. This has resulted in a significant financial challenge for the producers, and the trees have been cut down. Furthermore, it has led to the loss of foreign market shares.

As regards the impact on the forestry activities, the following effect can be categorized.

a- The insect may affect the rejuvenation of natural forests. In fact, they led to damage by feeding on the seeds of all coniferous species, which results in the reduction of seed sources and impairment of germination capacities. Therefore, insufficient seed source may pose a challenge during the natural regeneration efforts.

b- Seedling efforts may effected since the seeds with impaired germination capacity will not yield sufficient number of seedlings problems may be faced in the seedling production schemes. The cones should be cut and checked during seed collection stage and seeds should be collected more than planned and maintained in cold storages.

c- Another impact is the cost of the control measures against Leptoglossus occidentalis. If the insect adapts to the circumstances in Turkey, it is inevitable that there will be changes in its biological cycle. Since it is impossible to control the insect without being aware of its biological cycle, the control efforts will be ineffective.

d- In addition, this harmful insect is the shrinkage of the genetic basis during the natural regeneration efforts.

\section{Acknowledgements:}

The summary of the article is presented at the International Forest Symposium (2016Kastamonu). I would like to thank my colleagues for their help and support. 


\section{Reference}

Ahn SJ, et al. (2013). The first record on Leptoglossus occidentalis (Hemiptera: Coreidae) in Korea, a potential pest of the pinaceous tree species. J Asia Pacific Entomol 16(3):281-284. Doi:10.1016/j.aspen.2013.04.001.

Anonymous 1. Bursa Orman Fidanlık Müdürlüğü ile yapılan sözlü görüşme.

Arslangündoğdu, Z. ve Hizal, E. (2010). The Western Conifer Seed Bug, Leptoglossus occidentalis (Heidemann, 1910), recorded in Turkey (Heteroptera: Coreidae) Zoology in the Middle East 50, s. 138139.

Bates S.L. et al. (2002a). Abortion and seed set in lodgepole and western white pine conelets following feeding by Leptoglossus occidentalis (Heteroptera: Coreidae).- Environmental Entomology, 31: 1023-1029.

Bates SL, et al. (2000). Impact of Leptoglossus occidentalis (Hemiptera: Coreidae) on Douglas-fir seed production. $J$ Econ Entomol 93(5):1444- 1451. doi:10.1603/0022-0493-93.5.1444).

Bates SL, et al. (2001). Effect of feeding by the western conifer seed bug, Leptoglossus occidentalis, on the major storage reserves of developing seeds and on seedling vigor of Douglas-fir. Tree Physiol 21(7):481-487.

Bates, S. L. et al. (2002b). Measuring the impact of Lepfoglossus occidentalis (Heteroptera: Coreidae) on seed production in lodgepole pine using an antibody-based assay. J. Econ. Entomol. 95: 770-777.

Bates' S.L. (1997). Damage to common plumbing materials caused by overwintering Leptoglossus

occidentalis (Hemiptera: Coreidae) Department of Entomology, New York State Agricultural Experiment Station, Cornell University, 630 West North Street, Geneva, New York 14456, United States of America.

Blatt S.E. (1994). An unusually large aggregation of the western conifer seed bug, Leptoglossus occidentalis (Hemiptera: Coreidae), in a man-made structure. Journal of the Entomological Society of British Columbia,91:71-72.

Bracalini, M. et al. (2013). Cone and Seed Pests of Pinus pinea: Assessment and caracterization of Damage DOI: http://dx.doi.org/10.1603/EC12293 229234First published online: 1 February 2013

Bracalini, M., et al. (2014). DNA based markers to characterize insect pest damage: diagnostic trials on Leptoglossus occidentalis (Hemiptera: Coreidae), Entomology 2014, ESA 62ND Annual Meeting November 16-19, Portland OR.

Brambila, J. (2007). Heteroptera of Concern to Southern U.S S.Invasive Arthropod workshop, Southern Plant Diagnostic Network, 79 May 2007 - Clemson, South Carolina.

Campbell, B.C. and Shea, P.J. (1990). A simple staining technique for assessing Petrakis: First record of Leptoglossus occidentalis in Greece 89 feeding damage by Leptoglossus occidentalis Heidemann (Hemiptera: Coreidae) on cones. Canadian Entomologist 122: 963-968.

Chun-Sik Yoon, et al. (2012). First Record of the Western Conifer Seed Bug, Leptoglossus ccidentalis Heidemann (Heteroptera: Coreidae) in Korea., Journal of the Environmental Sciences, 1009-1013.

Cibrian-Tovar DB, et al. (1986). Leptoglossus occidentalisHeidemann. In:Cone and Seed Insects of the Mexican Conifers, , USDA Forest Science, Southeastern Forest Experiment Station, Ashville (US), pp.55-58.

DeBarr, G. L. and Kormanik, P. P. (1975). Anatomical basis for conelet abortion on Pinus echinata following feeding by Leptoglossus corculus (Say). Can. Entomol. 107:81-86.

Dusoulier, F. et al. (2007). L'invasion orientale de Leptoglossus occidentalis en France: bilan de son extension biogéographique en 2007 (Hemiptera: Coreidae). Entomologiste (Paris) 63: 303308.

EPPO. (2010). Leptoglossus occidentalis: an invasive alien species spreading in Europe. EPPO Reporting Service 1: 8-12. 
feeding of Leptoglossus occidentalis (Hemiptera: Coreidae). The Canadian Entomologist.

Fent M. and Kment P. (2011). First record of the invasive western conifer seed bug Leptoglossus occidentalis Heteroptera: Coreidae) in Turkey.- The North-Western Journal of Zoology, 7: 72-80.

Fleischer, F. et al. (2010). Prelımınary Investigation of The Effect Of PreDispersal Seed Predation On The Germination Of Quercus Candicans Née Acorns, Agrociencia 44: 83-92. 2010.

Galli, W.K. (1992). Further Eastern range extension and host records for leptoglossus occidentalis (heteroptera: core1dae): well-documented dispersal of a household nuisance, The great lakes entomologist, S 159-172.

Gapon, D. A. (2012). Izdatel'stvo Nauka, St. Petersburg, Russia Citation Ėntomologicheskoe Obozrenie, 91, 3, pp 559-568Gullan and Cranston, 2012. The Insects: An Outline of Entomology, Wiley-Blackwell; 4th Edition edition, ISBN-13: 978-1444330366, $584 \mathrm{p}$.

Hedlin, A.F., et al. (1981). Cone and seed insects of North American conifers. Canadian Forestry Service, Ottawa, USDA Forest Service, Washington D.C. and Secretaria de Agricultura y Recursos idraulicos, Mexico.

Hellrigl K. (2006). Rasche Ausbreitung eingeschleppter Neobiota (Neozoen undNeophyten)-Amerikanische

Koniferenwanze Leptoglossus occidentalis Heidemann, 1910.- Forest Observer, 2/3: 363-365.

Ishikawa, T. and Kikuhara, Y. (2009). (Leptoglossus occidentalis Heidemann (Hemiptera: Coreidae), a presumable recent invader to Japan). Japanese Journal of Entomology (New Series) 12: 115- 116. [in Japanese, English abstract].ISSN 1721-8861.

İktüeren, Ş. (1980). Fıstık Çamı Kozalak ve Tohumuna İlişkin Morfolojik ve Fizyolojik Araştırmalar. Ormancilık Araştırma Enstitüsü Yayınları, Teknik Bülten Seri No: 124, 40 s. Ankara.

Jamâa, M.L.B. et al. (2013). Detection of Leptoglossus occidentalis Heidemann,
1910 (Heteroptera: Coreidae) in Tunisia, African Entomology 21(1):165-167. doi: http://dx.doi.org/10.4001/003.021.0105.

Jucker, C. (2005). New exotic parasites and proposals for their control, Istituto di Entomologia Agraria) (Fondazione Minoprio, Vertemate con Minoprio, Como (Italy).

Kılcı, M. et al. (2014). Fistıkçamı (Pinus pineaL.) $420 \mathrm{p}$.

Koerber, T.W. (1963). Leptoglossus occidentalis (Hemiptera, Coreidae), a Newly Discovered Pest of Coniferous Seed. Annals of the Entomological Society of America 56: 229-234.

Krugman S. L. and Koerber T. W. (1969). Effect of cone feding by Leptoglossus occidentalis on ponderosa pine seed development.- Forest Science, 15: 104111.

Lesieur, V. et al. (2014). A simple staining technique for assessing feeding damage by Leptoglossus occidentalis Heidemann (Hemiptera: Coreidae) on cones.Biological Invasions, 16, 9, pp 1833-1849 Springer, Amsterdam, Netherlands.

Maltese, M. et al. (2009). Primi reperti in Sicilia su diffusione e biologia di Leptoglossus occidentalis Heidemann (Heteroptera: Coreidae), cimice americana dei semi delle conifere. pp. 1413-1418. In: Atti del Terzo Congresso.

Mjøs, A.T. et al. (2010). The Western Conifer Seed Bug (Leptoglossus occidentalis Heidemann, 1910) (Hemiptera, Coreidae) found in SW Norway. Norwegian Journal of Entomology 57: 20-22.

Mutke, S. et al. (2015). Pine nut production from forests and agroforestry systems around the Mediterranean - a short verview, Workshop and MC Meeting Zagreb | 18. - 20. February.

Ogden, J. (2013). Western Conifer Seed Bug, Insectary Notes, NS Dept. of Natural Resources Forest Health, October / November p. 2-3.

Özçankaya, M. et al. (2010). Kozak Yöresindeki Fıstıkçamlarında (Pinus pinea L.) Biyotik Faktörler ile Besin Elementlerinin Kozalak Kayıplarına Etkileri, Teknik Bülten No 47, Bakanlık 
Yyain No, 399, Müdürlük Yayın No, 62, 56 sayfa, İzmir.

Peverieri, S. et al. (2013). Host Egg Age of Leptoglossus occidentalis (Heteroptera, Coreidae) and Parasitism by Gryon pennsylvanicum (Hymenoptera, Platygastridae)

DOI: http://dx.doi.org/10.1603/EC12344 633-640 First published online: 1 April 2013.

Reid, S. et al. (2009). Western Conifer Seed Bug Leptoglossus occidentalis, Plant Pest Factsheet Societá Veneziana di Scienze Naturali Lavori, 26: 3-5.storage reserves and seedling vigour in Douglas-fir. Master of Pest Management thesis, Simon Fraser University, Burnaby.

Resh, W.H. and Carde, T. (2009). Encyclopedia of INSECTS, Second edition 2009, Copyright 2009, Elsevier, Inc. All rights reserved. ISBN: 978-0-12374144-8.

Roversi, P.F. (2009). Adattamento di specie neo-introdotte, Leptoglossus occidentalis Heidemann. In: Jucker, C., Barbagallao, S., Roversi, P.F., Colombo, M. (Eds.), Insetti esotici e tutela ambientale. Arti Grafiche Maspero Fontana \& C., Cermenate, Italy, pp. 224-229.

Roversi, PF. et al. (2011). Introduction into Italy of Gryon pennsylvanicum (Ashmead), an egg parasitoid of the alien invasive bug Leptoglossus occidentalis Heidemann. EPPO Bull 41(1):72-75. doi:10.1111/ j.1365-2338.2011.02439.

Santini, L. (2009). La cimice americana delle conifere (Leptoglossus occidentalis Heidemann) (Heteroptera, Coreidae) e fruttificazione del pino domestico, in:Insetti di recente introduzione dannosi alle pinete, I Georgofili, Quaderni 2009 IV sezione Centro-Ovest, supplement to Atti dell'Accademia dei Georgofili anno 2009 serie VIII vol. 6. Felici Pubblishing, Pisa, Italy, pp. 15-36.

Sousa E. et al. (2014). Iufro Joint Meeting 2014. New data about biotic factors that affect stone pine production in Portugal.Antalya/Turkey -09-14 April.

Sousa,E., Naves,P. (2011). The western conifer seed bug Leptoglossus occidentalis Heidemann, 1910 (Heteroptera: Coreidae) in Portugal Bol. San. Veg. Plagas, 37: 65-67,2011, Entomologist 133:857-865.

Strong, W. B. et al. (2001). Feeding by Leptoglossus occidentalis (Hemiptera: Coreidae) reduces seed set in lodgepole pine (Pinaceae), The Canadian Entomologist/Volume 133/Issue 06/pp 857-865.

Strong, W. B. (2006). Seasonal changes in seed reduction in lodgepole pine cones caused by feeding ofLeptoglossus occidentalis (Hemiptera: Coreidae), The Canadian Entomologist/Volume 138/Issue 06/pp 888-896.

Tamburın1, M. et al. (2012). Adaptation of the invasive western conifer seed bug Leptoglossus occidentalis to Trentino, an alpine region (Italy) Bulletin of Insectology 65 (2): 161-170, ISSN 17218861.

Tescari, G. (2001). Leptoglossus occidentalis, coreidae neartino rinvenuto in Italia (Heteroptera, Coreidae). Torymidae) native and introduced to the West Palearctic region: taxonomy, host specificity and distribution. J Naturali, Lavori 26: 3-5.

URL 1.http://www.hurriyet.com.tr/kilosu130-lira-ama-yetistiricisi-mutsuz40044617, 24 Ocak 2016.

Walker, E.M. (1913). The canadian Entomoligist Volume XLV, Editor Emeritus : REV. C. J. S. Bethune. Ontario Agricultural College, Guelph, Ont. ILontion, Cntario: The London Printing and Lithographing Company Limited.

Wittenberg, R. (2005). An inventory of alien species and their threat to biodiversity and economy in Switzerland. Report to the Swiss Agency for the Environment, Forests and Landscape SAEFL. CABI Bioscience Switzerland Centre, Deléont, Switzerland $417 \mathrm{pp}$.

Woods, J. et al. (2015). Impact of Matador on lodgepole pine filled seed production in southern interior BC seed orchards: 2014 trial. 